\title{
Population density of Meloidogyne incognita on sunflower as affected by certain organic composts under field conditions
}

\author{
M. M. M. Mohamed, E. M. A. Noweer and Susan A. Hasabo \\ Nematology Laboratory, Plant Pathology.Department, \\ National Research Centre, Dokki, Cairo, Egypt \\ Email:moawad_bondok@yahoo.com \\ ABSTRACT
}

\begin{abstract}
The effect of three composts viz., pigeon, sheep and cattle applied at three different times were studied under field conditions. These composts were applied as soil amendments for control of Meloidogne incognita at the rates of 2,4 and 8 tons/ feddan to sunflower cv. Euroflower 40 days after decomposition before planting (season, 2006), at planting time (season, 2007) or left for a week to allow decomposition before planting (season 2008). All the tested materials significantly ( $p \leq 0.05 / 0.01$ ) reduced the number of galls, egg masses and second stage larvae in soil as compared to untreated check and increased the weight of flowering discs, specially, dose 4 tons per feddan at three season 2006, 2007 and 2008, respectively. Composts application inhibit pathogenic fungi as Pythium sp. and Alternaria sp. growth and increased number of beneficial fungi as Trichoderma harzianum, Arthrobotrys conoides and Dactylaria brochopaga.
\end{abstract}

Keywords: Organic composts, Meloidogyne incognita, Sunflower.

\begin{abstract}
INTRODUCTION
Numerous methods are available for managing certain pathogenic plant parasitic nematodes (Mcsorley 1994; Mcsorley and Duncan' 1995). The advantages of organic amendments in improving crop performance are well known (Gallaher and Mcsarley 1994 and 1995). Organic matter and new composts are given a major attention. As a matter of fact, organic matter affects nematode populations in two different ways directly by processing nematicidal properties during its degradation (Sitaramaiah and Singh 1978), or indirectly by enhancing the development of nematode natural enemies ( $D^{\prime}$ Errico and Maio, 1980), improving crop performance to increase tolerance to nematode (Trivedi and Barker 1986 and Novaretti et al., 1985) on improving porosity, cation exchange capacity, soil water holding capacity and crop nutrition (Kostewiez 1993 and Gallaher and Mcsorley 1994). Therefore some additives such as soil amendments were tested against root-knot nematode to minimize environmental pollution and keep management processes more economical.
\end{abstract}

In continuation, the present investigation was carried out to study the effect of certain organic composts as pigeon, sheep and cattle for improving the tolerance of sunflower cv. Euroflower against root-knot nematode, Meloidgyne incognita.

\section{MATERIALS AND METHODS}

This test was carried out in a clay loam soil field infested with Meloidogyne incognita in Kafr. Kandeel,
Attfeih, Giza Governorate, three composts viz., pigeon, cattle and sheep $10 \mathrm{~kg}$ from each compost was mixed with $50 \mathrm{~g}$ sulphur, $100 \mathrm{~g}$ ammonium sulphate, $100 \mathrm{~g}$ yeast, 3L. black honey and $3 \mathrm{~L}$ water. These composts were mixed with the soil at the rates of 2, 4 and 8 tons/ feddan $\left(4200 \mathrm{~m}^{-2}\right)$ at three different times viz., addition to the soil after compost decomposition for 40 days before planting (season, 2006), at planting time (season, 2007) and compost decomposition for a week before sunflower planting (season, 2008). Seeds of sunflower cv. Euroflower were sown in rows 10 meter long, $50 \mathrm{~cm}$ apart and the distance between hills $40 \mathrm{~cm}$. There were ten replicates for each treatment and all treatments were distributed in a randomized block design. After three months from cultivation, sunflower plants were harvested. Nematodes in soil were extracted from $200 \mathrm{~g}$ soil for each replicate by sieving and decanting methods (Barker, 1985). Number of galls, egg masses and second stage $\left(\mathrm{J}_{2}\right)$ in soil were counted from $5 \mathrm{~g}$ roots in each replicate. The soil samples (season, 2008) were microbiologically analyzed to determine certain fungi in them. Microbial analysis was carried out at National Research Centre, Department of Plant pathology, Cairo, Egypt. One gram of each soil sample of each treatment was added to $99 \mathrm{ml}$ of sterilized distilled water to give dilution of $10^{-2}$. Then serial dilution from $10^{-3}$ to $10^{-7}$ of fresh suspension of each soil treatment were prepared under sterilized conditions. The fungal count was determined by the total plate count agar method (Gnan and Demello 1999) using pair plate 
technique. The microbial counts were calculated as colony forming unit per gram (CFU ). Three replicates were prepared for each dilution of each sample. Concerning fungal count, Potato dextroxe agar (PDA) (Harwing, Scatte, Staltez and Blanch (1979) were used. The fungi that grew out identified according to their morphological characteristics (Barnett and Hunter, 1987). The frequency of occurrence for each fungus was calculated according to the following formula and expressed as:

The frequency of fungus $(\%)=$ number of each fungus $X 100$

$$
\text { No. total fungi }
$$

Data obtained on the percentage (\%) frequency occurrence of fungi presented in Table (4) according to the following scale:

Where: $(-)=$ no fungi, $(+)=1-10 \%,(++)=11-20 \%$, $(+++)=21-50 \%$ and $(++++)=51-100 \%$

Obtained results were statistically analyzed using Duncan's multiple rang test (Duncan, 1955).

\section{RESULTS}

Data on the effect of pigeon, sheep and cattle waste composts as affected by the time of application were illustrated in tables $(1,2$ and 3$)$. In the first case (Table 1), when the tested composted were added to the soil 40 days after decompostion (season, 2006), the numbers of galls, egg masses and $J_{2}$ in soil were differently reduced according to the tested materials. In general, the tested nematode parameters were inversely proportional tested rates of materials i. e. as higher rate of the tested materials, lower number of root-knot nematode. In the second case (Table 2), when the composts was added to the soil at planting time, the tested composts behaved the same trend as the lowest nematode numbers occurred in the highest rate of composts ( 8 ton/feddan), followed by those the immediate rate and the lowest rate of application. In the third case (Table,3), when the tested composts were added to the soil and left for a week to allow decomposition before planting , the reduction in nematode numbers differed according to rates and tested materials, but there is no definite trend for this reduction. As for yield of sunflower as indicated by weight of flowering disc, it increased by the different compost wastes and these increases with the different materials and time of application. In general, higher weight of flowering disc occurred by using cattle compost (4 tons/ feddan), 32.22\%, $28.40 \%$ and $57.81 \%$ (seasons 2006, 2007 and 2008), respectively and when three composts were added to the soil and left for a week to allow their decomposition before planting in season 2008 (Table,3).

Data obtained on the micro organesims associated with the different concentrations of tested composts revealed that the most tested composts decreased pathogenic fungi as Pythium sp. , Fusarium $s p$. and Alternaria sp. and increased beneficial fungi as Trichoderma harzianum, Arthrobotrys conoides and Dactylaria brochopage frequencies during season, 2008 (Table 4).

\section{DISCUSSION}

In the present investigation, certain compost wasts were effective in lowering root galls, egg masses and fecundity of $M$. incognita and in increasing of sunflower yield as indicated by weight of flowering disc. When the composts were added to the soil and left for a week for maturation before sunflower planting (season 2008), it increased nematode reduction higher than when composts were added to the soil after 40 days from decomposition for (season, 2006) or added to the soil at planting time (season, 2007). This may be due to the period of decomposition. Breakdown of organic materials may release toxic and nematicidal substances that contribute to nematode control (Rodriguez - Kabana et al. 1981, 1982, Thakar et al., 1988 and Aboul- Eid et al., 1998). Linford and Linford et al. (1937 and 1938) demonstrated that the reduction of nematode population in soil amended with compost material may be due to increase in numbers of fungi, nematodes, mites and other microorganisms that are parasitic or predacious to developmental stages of plant parasitic nematode or to stimulation of selected microorganisms capable of decomposing the proteins or other materials that make up nematode cuticles or other structures. Also, free-living nematode have been reported to accelerate the decomposition of soil amendments and increase the mineralization of $\mathrm{N}$ and $P$ releasing nutrients for plant growth. Johnson (1974) reported that the reduction of phytonematodes may be attributed to accelerate proliferation of the microbial forms which capable of synthesizing and producing substances toxic to plant parasitic nematodes or to directed toxicity of the products of ammonification 
Agric. Biol. J. N. Am., 2011, 2(5): 729-733

Table 1. Effect of organic manures (compost) addition to the soil after decomposition for 40 days before planting on root-knot nematode, Meloidogyne incognita infesting sunflower under field conditions at seson (2006).

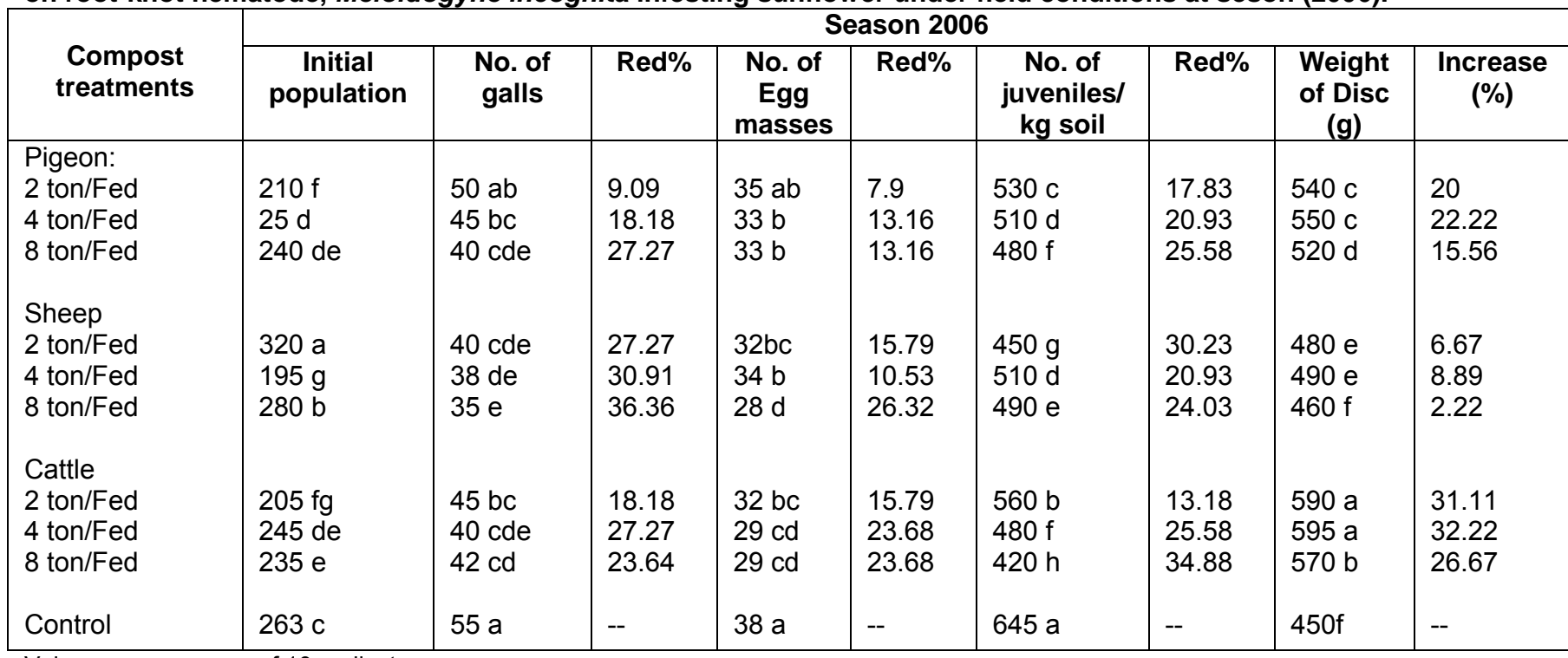

Values are averages of 10 replicates.

Fed $=$ Feddan

Reduction $\%=$ Red $\%=\frac{\text { control- treated }}{\text { Control }} \times 100$

Data with the same letters within a column are not significantly different according to Duncan's multiple range test.

Table 2. Effect of organic manures (compost) addition to the soil at planting time on root-knot nematode, Meloidogyne incognita infesting sunflower under field conditions at seson (2007).

\begin{tabular}{|c|c|c|c|c|c|c|c|c|c|}
\hline \multirow[b]{2}{*}{$\begin{array}{l}\text { Compost } \\
\text { treatments }\end{array}$} & \multicolumn{9}{|c|}{ Season 2007} \\
\hline & $\begin{array}{c}\text { Initial } \\
\text { population }\end{array}$ & $\begin{array}{l}\text { No. of } \\
\text { galls }\end{array}$ & Red\% & $\begin{array}{c}\text { No. of } \\
\text { Egg } \\
\text { masses }\end{array}$ & Red\% & $\begin{array}{c}\text { No. } \\
\text { juveniles/ } \\
\text { kg soil }\end{array}$ & Red\% & $\begin{array}{l}\text { Weight } \\
\text { of Disc } \\
\text { (g) }\end{array}$ & $\begin{array}{c}\text { Increas } \\
\text { e (\%) }\end{array}$ \\
\hline Pigeon: & & & & & & & & & \\
\hline 2 ton/Fed & $260 \mathrm{f}$ & $53 \mathrm{bc}$ & 14.52 & $38 \mathrm{bcd}$ & 13.64 & $480 \mathrm{c}$ & 9.43 & $450 \mathrm{de}$ & 11011 \\
\hline 4 ton/Fed & $305 d$ & 52 bc & 16.13 & $37 \mathrm{~cd}$ & 15.91 & 420de & 20.76 & 490 c & 20.99 \\
\hline 8 ton/Fed & $280 \mathrm{e}$ & $48 \mathrm{~cd}$ & 22.58 & $31 \mathrm{e}$ & 29.55 & $430 \mathrm{~d}$ & 18.87 & 440 ef & 8.64 \\
\hline Sheep & & & & & & & & & \\
\hline 2 ton/Fed & $360 a$ & $56 a b$ & 9.68 & $45 a$ & -2.27 & $430 \mathrm{~d}$ & 18.87 & $430 \mathrm{f}$ & 6.17 \\
\hline 4 ton/Fed & $320 c$ & 52 bc & 16.13 & $41 \mathrm{abc}$ & 6.82 & $505 b$ & 4.72 & $460 \mathrm{~d}$ & 13.58 \\
\hline 8 ton/Fed & $340 \mathrm{~b}$ & $48 \mathrm{~cd}$ & 22.58 & $34 \mathrm{de}$ & 22.73 & $410 \mathrm{e}$ & 22.64 & $410 \mathrm{f}$ & 1.24 \\
\hline Cattle & & & & & & & & & \\
\hline 2 ton/Fed & $210 \mathrm{~g}$ & $45 d$ & 27.42 & $38 \mathrm{bcd}$ & 13.64 & $485 \mathrm{c}$ & 8.49 & $510 a b$ & 25.93 \\
\hline 4 ton/Fed & $205 \mathrm{~g}$ & $56 a b$ & 9.68 & $42 a b$ & 4.55 & $420 \mathrm{de}$ & 20.76 & 520 a & 28.40 \\
\hline 8 ton/Fed & $355 a$ & $51 \mathrm{bcd}$ & 17.74 & $36 \mathrm{~d}$ & 18.18 & $390 \mathrm{f}$ & 26.42 & 50 bc & 23.46 \\
\hline Control & $280 \mathrm{e}$ & $62 a$ & -- & $44 a$ & -- & $530 a$ & -- & $405 \mathrm{f}$ & -- \\
\hline
\end{tabular}

Fed $=$ Feddan $=4200 \mathrm{~m}^{2}$

Reduction $\%=\operatorname{Red} \%=\frac{\text { control- treated }}{\text { Control }} \times 100$

Increase $=\frac{\text { treated- control }}{\text { Control }} \times 100$ 
Table 3. Effect of organic manures (compost) addition to the soil after a decomposition for a week before planting on root-knot nematode, Meloidogyne incognita infesting sunflower under field conditions at seson (2008).

\begin{tabular}{|c|c|c|c|c|c|c|c|c|c|}
\hline \multirow[b]{2}{*}{$\begin{array}{l}\text { Compost } \\
\text { treatments }\end{array}$} & \multicolumn{9}{|c|}{ Season 2008} \\
\hline & $\begin{array}{c}\text { Initial } \\
\text { population }\end{array}$ & $\begin{array}{l}\text { No. of } \\
\text { galls }\end{array}$ & Red\% & $\begin{array}{c}\text { No. of } \\
\text { Egg } \\
\text { masses }\end{array}$ & Red\% & $\begin{array}{c}\text { No. of } \\
\text { juveniles/ } \\
\text { kg soil }\end{array}$ & Red\% & $\begin{array}{l}\text { Weight } \\
\text { of Disc } \\
(g)\end{array}$ & $\begin{array}{c}\text { Increase } \\
(\%)\end{array}$ \\
\hline Pigeon: & & & & & & & & & \\
\hline 2 ton/Fed & $153 \mathrm{~b}$ & $4 \mathrm{e}$ & 73.33 & $1 \mathrm{~d}$ & 85.71 & $32 e$ & 95.79 & $480 \mathrm{~b}$ & 50.00 \\
\hline 4 ton/Fed & $23 \mathrm{e}$ & $2 f$ & 86.67 & $1 \mathrm{~d}$ & 85.71 & $18 \mathrm{f}$ & 97.63 & $510 a$ & 59. 40 \\
\hline 8 ton/Fed & $52 \mathrm{~d}$ & 3 ef & 80.00 & $1 \mathrm{~d}$ & 85.71 & 24 ef & 96.84 & $480 \mathrm{~b}$ & 50. 00 \\
\hline Sheep & & & & & & & & & \\
\hline 2 ton/Fed & $48 d$ & $13 \mathrm{c}$ & 13.33 & $7 \mathrm{~b}$ & 0 & $44 \mathrm{~d}$ & 94.21 & $420 \mathrm{~d}$ & 31.25 \\
\hline 4 ton/Fed & $21 \mathrm{e}$ & $2 f$ & 86.67 & $1 \mathrm{~d}$ & 85.71 & $19 \mathrm{f}$ & 97.50 & $450 \mathrm{c}$ & 40.63 \\
\hline 8 ton/Fed & $26 \mathrm{e}$ & $8 \mathrm{~d}$ & 46.67 & $3 c$ & 57.14 & 25 ef & 96.71 & $420 \mathrm{~d}$ & 31.25 \\
\hline Cattle & & & & & & & & & \\
\hline 2 ton/Fed & $87 c$ & 3 ef & 80.00 & $1 d$ & 85.71 & $103 \mathrm{~b}$ & 86.45 & $500 \mathrm{a}$ & 56.25 \\
\hline 4 ton/Fed & $51 d$ & $23 a$ & -53.33 & $10 a$ & -42.86 & $60 \mathrm{c}$ & 92.11 & $505 a$ & 57.81 \\
\hline 8 ton/Fed & $52 \mathrm{~d}$ & 3 ef & 80.00 & $2 \mathrm{~cd}$ & 71.43 & $45 d$ & 94.08 & $480 \mathrm{~b}$ & 50.0 \\
\hline Control & $588 a$ & $15 b$ & -- & $7 b$ & - & $760 \mathrm{a}$ & - & $320 \mathrm{e}$ & - \\
\hline
\end{tabular}

Fed $=$ Feddan $=4200 \mathrm{~m}^{2}$

Table (4): Effect of the tested composts on the frequency occurrence percentages of fungal genera and species in soil (season, 2008).

\begin{tabular}{|c|c|c|c|c|c|c|c|c|c|c|c|c|c|c|c|c|c|c|}
\hline \multirow{3}{*}{$\begin{array}{l}\text { Composts } \\
\text { Treatment }\end{array}$} & \multicolumn{18}{|c|}{ Soil fungi } \\
\hline & \multicolumn{3}{|c|}{ Pythium sp. } & \multicolumn{3}{|c|}{ Fusarium sp } & \multicolumn{3}{|c|}{ Alternaria sp. } & \multicolumn{3}{|c|}{$\begin{array}{c}\text { Trichoderma } \\
\text { harzianum }\end{array}$} & \multicolumn{3}{|c|}{$\begin{array}{c}\text { Arthrobotrys } \\
\text { conoides }\end{array}$} & \multicolumn{3}{|c|}{$\begin{array}{c}\text { Dactylaria } \\
\text { brochopaga }\end{array}$} \\
\hline & $\mathbf{a}$ & $\mathbf{m}$ & $f$ & a & $\mathbf{m}$ & $f$ & $\mathbf{a}$ & $\mathbf{m}$ & $f$ & $\mathbf{a}$ & m & $f$ & a & $\mathbf{m}$ & $f$ & a & m & $f$ \\
\hline Pigeon & + & + & - & + & - & - & + & - & - & - & + & ++ & - & + & + & - & - & - \\
\hline Sheep & - & + & + & + & + & - & + & + & - & - & + & + & - & - & - & - & - & - \\
\hline Cattle & + & - & + & - & + & - & + & - & + & - & ++ & + & - & - & - & - & + & ++ \\
\hline Control & + & + & + & - & + & + & + & + & ++ & - & - & - & - & - & - & - & - & - \\
\hline
\end{tabular}

$a=$ initial, $m=$ mid season

$\mathrm{f}=$ final season, $(-)=$ no fungi $(+)=1-10 \%,(++)=11-20 \%$

During decomposition of the organic materials (Mian et al 1982). Free ammonia permeates cellular membranes much more readily than ionized ammonia. While ammonia is an important source of nitrogen for living plants, high concentrations of ammonia in the soil have been shown to be phytotoxic, inhibiting germination. Also, organic residues have been increased some microorganisms in soil , specially fungi (Jaffw et al., 1998, Duldington, 1957) which may act as biological agent of nematodes as Trichoderma harzianum which is known to produce endochitinase affecting eggshell of nematode (Lorits et al; 1998) and Arthrobotrys conoides and Dactylaria brochopaga which are considered nematode trapping fungi (Duponnois et al; 1997, Al- Hazmi et al; 1993 and Aboul- Eid et al; 2006). Finally, this approach of nematode control has an advantage over the use of nematicidal chemicals, since it is less expensive, safer and easy to apply with no pollution risks and can improve soil structure and fertility.

\section{REFERENCES}

Aboul- Eid H. Z. Ismail A. E and Abd. El-Fattah A. E. (1998). Effects of certain composted plant residues on sunflower plants infected with Meloidogyne incognita. Egypt. J. Agronematol. 2(1): 79- 95.

Al- Harzmi A. S.,. Ibrahim A. A. M and. Abdul- Raziq A. T (1993). Evaluation of a nematode- encapsulating fungi complex for control of Meloidogyne javanica on potato. Pak. J. Nematol.11, 139- 149. 
Barker, T. R. (1985). Nematode extraction and bioassays, Pp 19- 35In: An Advanced treatise on Meloidogyne Vol. 2. T. R., Carter, C. C. and Sasser JN (Eds). North Carolina state University.

Barnett H. L. and. Hunter B. B (1987). Illustrated Genera of Inperfect Fungi $4^{\text {th }}$. Ed., 1-97, Mac, Millan Publishing Co. New York, USA

Bridson, E. Y. (1995). The oxide manual . $7^{\text {th }}$. Ed., published by unipath Limited Wade Koad, Basingstoke Hampshire, R G 248 PW, England.

D' Errico F. P. and Di Maio F. (1980). Effect of some organic material on root-knot nematodes on tomatoes in field preliminary experiments. Nematol. Medit. 8: 107- 110

Duldington, C. L. (1957). The friendly fungi. Faber nd Faber London.

Duncan, D. B. (1955). Multiple Range and Multiple F. Tests Biometrics 11, 1-42.

Duponnois R., T. Mataille and A. Ba (1997). Potential effects of Sahelian nematophagous fungi against Meloidogyne mayaguensis on tobacco. Annales due Tabac Section. 2, No. 29, 61-70.

Gallaher, R. N. and Mcsorley R. (1994). Management of yard waste compost for soil amendment and corn yield. P. 156- 160. In: P. J. Bauer and W. J. Busscher (Eds). Proceedings of the. Southern Conservation Tillage Conference for Sustainable Agriculture. USDAARSC Coustal Plains: Soil, water and Plant Research Centre.

Gallaher, R. N. and Mcsorley R. (1995). No. Tillage field corn and vegetables using yard waste compost. P. 16 18. In: W. L. Kingery and N. Buehring (Eds). Proceedings of the 1995 Southern conservation Tillage Conference for Sustainable Agriculture. Mississipi state University Mississipi State, ME.

Gnan, S. O and M. Demello T. (1999). Inhibition of Staphylocous aureus by aqueous Goiaba extracts. J. Ethno pharmacol. 68: 103- 108.

Harwing J; Scatte, Staltaz P.M; SOC. D. R. and Blanch field B. J. (1979). Toxins of malds from decaying tomato fruit. Appl. Environ Microbio. 38 (2) 267- 274.

Jaffee B. A.,. Ferris H and. Scow K. M (1998). Nematodetrapping fungi in organic and conventional cropping systems. Phytopathology 88 (4): 344- 350.

Johnson L. F. (1974). Extraction of oat straw, flax and amended soil to detect substances toxic to the rootknot nematode. Phytopathol., 64: 1471- 1474.

Kostewiez S. R. (1993). Pole bean yield as influenced by composted yard waste soil amendments. Proc. Florida state Hort. Soc. 106: 206- 208.
Linford M. B. (1937). Stimulated activity of natural enemies of nematodes. Science, 85: 123- 141.

Linford M. B.; Yap, F. and oliveira, J. M. (1938). Reduction of soil Population of root-knot nematode during decomposition of organic matter. Soil Sci. 45: 127141.

Lorits, M,. Woo S. L L. Fernandes. G. Colucci, G. Harman G. E.. Pintor,T. J. A E. Filippone, S. Muccifora, C. B. Lowrence, A. Zoina, S. Tuzan and F. Scalon (1998). Genes from mycoparasitic fungi as a source for improving plant resistance to fungal pathogens. Proc. Nat. Acad. Sci. of United States of America. 95: 79607865.

Main I. H; Godoy, G.; Shelby, R. A.; Rodrigue 2- kabna, R. and Morgan- Jones, G. (1982). Chitin amendments for control of Meloidogyne arenaria infested soil. Nematropica 12: 71- 84.

Mcsornley, R. (1994). Nematode management in sustainable agriculture. P. 517- 522. In: K. L. Campele, W. D. Graham and A. B. Bottcher (eds). Environmentally sound Agriculture, Proceedings of the second Conference. Amer. Soc. Agric. Eng St. Joseph, $\mathrm{MI}$.

Mcsorley, R. and Duncan M. (1995). Economic thresholds and nematode management. Adv. Plant Pathol. 11. 147- 171.

Novaretti, W. R., Carderan J. O. Starbelli J. and. Amorim. E (1985). Effect of compost application alone or incombination with nematicide and mineral fertilizers on nematode control and productivity of sugarcane. Nematol. Brasil. 13: 93- 107.

Rodriquez- Kabana, R., king, P. S. and Pope, M. H. (1981). Combinations of anhydrous ammonia and ethylene dibromide for control of nematodes parasitic in soybean. Nematropica 11, 27: 41.

Rodriquez- Kabana, R., Shelby, R. A., King, P. S. and Pope, M. H. (1982). Combinations of anhydrous ammonia and 1, 3 dich loropropenes for control of root-knot nematodes in soybean. Nematropica 12; 6196.

Sitaramarah, R. and R. S. Singh 1978. Effects organic amendments on phenolic content of soil and plant response of Meloidogyne javanica and its host to related compounds. Plant and Soil, 5: 671- 679.

Thakar, N. A., Patel, C. C. and Patel, H. R. (1988). Effect of extracts of Azolla Pinnata on egg-Hatching of rootknot nematodes, Meloidogyne incognita and $M$. javanica. Madras Agric. J. 75: 297- 299.

Trivedi, P. C. and Barker K. R. (1986). Management of nematodes by cultural practices, Nematropica, 16: 213- 236. 